\title{
Tissue carbon concentration of 175 Mexican forest species
}

\author{
Marín Pompa-García ${ }^{(1)}$, \\ José Angel Sigala-Rodríguez ${ }^{(2)}$, \\ Enrique Jurado ${ }^{(3)}$, \\ Joel Flores ${ }^{(4)}$
}

\begin{abstract}
Reliable calculations of carbon stocks in forest ecosystems are crucial for proper implementation of global warming mitigation policies. Accurate estimations depend upon applying the correct factor of carbon (C) concentration for different forest species and tissues instead of the often assumed $50 \%$ carbon content. Despite the high forest species richness in Mexico and the increasing $\mathrm{CO}_{2}$ emissions, data on carbon concentrations in forest plant tissues are scarce. In this study, we determined variation in C concentration of different tissues for 175 plant species common in Mexican forests. C contents were estimated and contrasted for plant distribution, taxa, and plant structure (main stems, branches, twigs, bark, leaves, buds, fruits, roots and root cuticles). The mean $C$ concentration across species was $44.7 \%$. Species significantly differed in $C$ concentration by tissue, environment and taxa. These multi-species data contribute to improve precision on estimates of $C$ balance in terrestrial ecosystems, reducing the uncertainty in $C$ inventories in Mexico and elsewhere.
\end{abstract}

\section{Keywords: Carbon Sink, Plant Tissue C, Multi-species C, Global Warming}

or over-estimate real C stocks (Yerena-Yamallel et al. 2011, Jiménez-Pérez et al. 2013), causing uncertainty in the potential of forests as C sinks (Lamlom \& Savidge 2003).

Variations in $C$ concentration between species is influenced by phylogeny and the environment (biotic and abiotic) in which plant species grow (Thomas \& Malczewski 2007). Different plant species may have a specific chemical composition and carbon compounds due to their metabolism, as physiology and morphology are linked to an optimal functioning under the ecological conditions where they have evolved (Sardans \& Peñuelas 2014). Within a given individual, $C$ concentration varies between tissues (Yeboah et al. 2014), depending to a larger extent on the chemistry of such tissues (Savidge 2003) than on plant age or size (Bert \& Danjon 2006). This study presents $C$ concentration values for 175 plant species in 18 families from temperate, trop-
(1) Universidad Juárez del Estado de Durango, Facultad de Ciencias Forestales, Río Papaloapan y Blvd. Durango s/n, Colonia Valle del Sur, C.P. 34120 Durango, Dgo. (México); (2) Campo Experimental Valle del Guadiana, Instituto Nacional de Investigaciones Forestales, Agrícolas y Pecuarias, Carretera Durango-Mezquital km 4.5, C.P. 34170, Durango, Dgo. (México); (3) Universidad Autónoma de Nuevo León, Facultad de Ciencias Forestales, A.P. 41, Carretera Nacional No. 85, Km 145, C.P. 67700, Linares, N.L. (México); (4) Instituto Potosino de Investigación Científica y Tecnológica, División de Ciencias Ambientales, Camino a la Presa San José No. 2055, Colonia Lomas 4a. Sección, San Luis Potosí, S.L.P., C.P. 78216 (México)

@ Enrique Jurado (enrique_jurado@hotmail.com)

Received: Mar 08, 2017 - Accepted: Jun 15, 2017

Citation: Pompa-García M, Sigala-Rodríguez JA, Jurado E, Flores J (2017). Tissue carbon concentration of 175 Mexican forest species. iForest 10: 754-758. - doi: 10.3832/ifor2421-010 [online 2017-08-05]

Communicated by: Ana Rey ical, subtropical, arid and semiarid zones in Mexico to establish whether and how biomass $C$ concentration differed across environments, taxa and plant tissues. Such dataset will help determine if the use of the generalized assumption of $50 \%$ C content is applicable for Mexican forests and similar ecosystems and species in other parts of the world.

\section{Material and methods}

\section{Experimental design and $\mathrm{C}$}

\section{concentration determinations}

A selective sampling of 175 representative forest species (Pompa-García et al. 2017) was carried out across Mexican environments. Sites were selected trying to encompass the large environmental variation but restricted by logging and accessibility. Temperate, tropical/subtropical and arid/ semiarid ecosystems were targeted as per González-Medrano (2003). In 68 localities in 17 states (Fig. S1 in Supplementary materials), at least three individuals from each of the 175 species, a sample of ca. $50 \mathrm{~g}$ (fresh mass) was taken from different plant parts following Henry et al. (2011): leaves $(\mathrm{L})$, buds $(\mathrm{Bd})$, fruits $(\mathrm{F})$, branches (B), bark from branches $(\mathrm{Bb})$, twig $(<5 \mathrm{~cm}$ in diameter - T), bark from twig (Bt), stem $(\mathrm{S})$, bark from stem (Bs), roots (R) and root cuticles (Rc). Only undamaged trees with no deformities were included in the study.

Samples were taken to the lab following the procedures described in Karlik \& Chojnacky (2014), and immediately (<24 hours) were placed and dried in the lab at room temperature to avoid loss of volatile substances (Avendaño et al. 2009, Martin \& Thomas 2011). Following the procedure by Lamlom \& Savidge (2003), we broke down the samples into small particles to better 
Tab. 1 - Carbon concentration for Mexican forest species studied by region and moisture regime. $(n)$ : number of species. Different letters indicate significantly different means $(p<0.05)$ after Tukey's test.

\begin{tabular}{llrc}
\hline Region & $\begin{array}{l}\text { Moisture } \\
\text { regime }\end{array}$ & $\mathrm{n}$ & $\begin{array}{c}\text { C Concentration } \\
\text { (\%, mean } \pm \text { sd) }\end{array}$ \\
\hline Temperate Zone & Semidry & 9 & $44.14 \pm 0.54^{\mathrm{ab}}$ \\
& Semihumid & 52 & $45.81 \pm 0.36^{\mathrm{a}}$ \\
Tropical and Subtropical & Humid & 72 & $44.35 \pm 0.23^{\mathrm{ab}}$ \\
zones & Semidry & 6 & $42.79 \pm 0.37^{\mathrm{b}}$ \\
& Subhumid & 4 & $44.16 \pm 0.30^{\mathrm{ab}}$ \\
Arid and semiarid zones & Semidry & 22 & $43.95 \pm 0.34^{\mathrm{ab}}$ \\
& Dry & 10 & $44.23 \pm 0.50^{\mathrm{ab}}$ \\
\hline
\end{tabular}

Fig. 1 - Differences in Carbon concentration between Magnoliophyta and Pinophyta. A higher $C$ concentration for species of Pinophyta was observed.

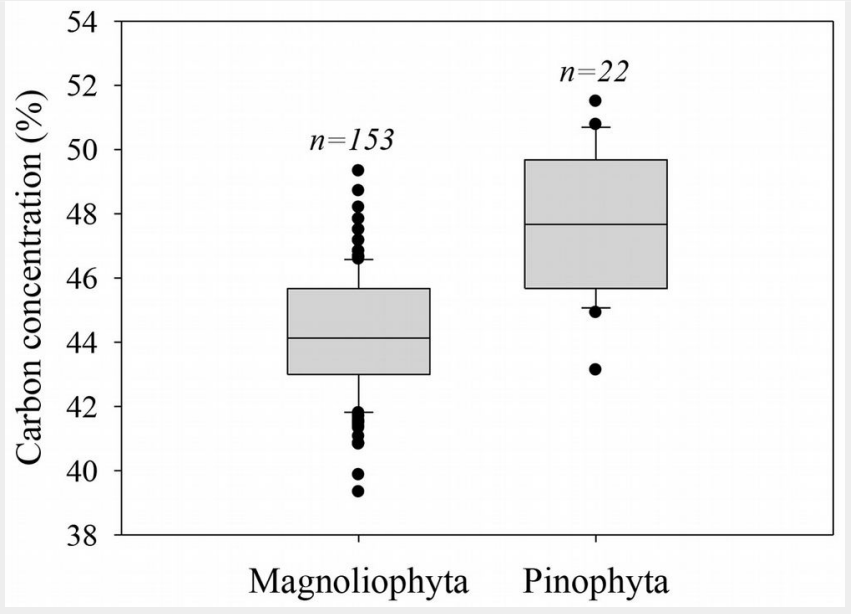

Tab. 2 - Mean and standard error of carbon concentration for 18 families. Only families with enough replicates were used in this analysis. Different letters indicate different means $(p<0.05)$ after Tukey's test.

\begin{tabular}{|c|c|c|c|}
\hline Order & Family & $\begin{array}{l}\text { Number } \\
\text { of species }\end{array}$ & $\begin{array}{c}\text { Carbon concentration } \\
(\%, \text { mean } \pm \mathrm{sd})\end{array}$ \\
\hline \multirow[t]{2}{*}{ Pinophyta } & Cupressaceae & 5 & $45.68 \pm 0.83^{\mathrm{bcd}}$ \\
\hline & Pinaceae & 16 & $48.29 \pm 0.50^{a}$ \\
\hline \multirow[t]{16}{*}{ Magnoliophyta } & Asparagaceae & 3 & $42.79 \pm 1.01^{\mathrm{e}}$ \\
\hline & Anacardiaceae & 7 & $45.01 \pm 0.69$ bcde \\
\hline & Arecaceae & 5 & $43.58 \pm 0.74^{\text {de }}$ \\
\hline & Bignoniaceae & 4 & $44.40 \pm 0.74^{\text {cde }}$ \\
\hline & Boranginaceae & 4 & $43.10 \pm 0.56^{\text {de }}$ \\
\hline & Burseraceae & 4 & $43.54 \pm 0.72$ de \\
\hline & Combretaceae & 3 & $42.82 \pm 0.52^{\mathrm{e}}$ \\
\hline & Ericaceae & 4 & $47.15 \pm 0.77$ \\
\hline & Fabaceae & 39 & $44.53 \pm 0.28^{a b}$ \\
\hline & Fagaceae & 17 & $44.29 \pm 0.41^{\text {cde }}$ \\
\hline & Malvaceae & 4 & $43.00 \pm 0.81^{\mathrm{e}}$ \\
\hline & Meliaceae & 3 & $43.41 \pm 1.21$ de \\
\hline & Moraceae & 8 & $43.41 \pm 0.55^{\mathrm{de}}$ \\
\hline & Rubiaceae & 5 & $44.81 \pm 0.49$ bcde \\
\hline & Salicaceae & 3 & $45.68 \pm 0.83^{\text {bcd }}$ \\
\hline & Sapotaceae & 3 & $48.29 \pm 0.50^{a}$ \\
\hline
\end{tabular}

Tab. 3 - Mean and standard error of carbon concentration of some of the genera sampled. Different letters indicate different means $(p<0.05)$. (*): Genera with at least tree sampled species were included to comply with assumptions of analysis of variance.

\begin{tabular}{lcc}
\hline Genus* & $\begin{array}{c}\text { Number } \\
\text { of species }\end{array}$ & $\begin{array}{c}\text { Carbon concentration } \\
\text { (\%, mean } \pm \text { sd) }\end{array}$ \\
\hline Acacia & 7 & $43.93 \pm 0.42^{\mathrm{b}}$ \\
Bursera & 3 & $42.89 \pm 0.44^{\mathrm{b}}$ \\
Cordia & 3 & $43.08 \pm 0.79^{\mathrm{b}}$ \\
Ficus & 6 & $43.08 \pm 0.53^{\mathrm{b}}$ \\
Pinus & 12 & $48.96 \pm 0.51^{\mathrm{a}}$ \\
Pithecellobium & 3 & $43.92 \pm 0.96^{\mathrm{b}}$ \\
Quercus & 17 & $44.29 \pm 0.41^{\mathrm{b}}$ \\
\hline
\end{tabular}

estimate $C$ content using a pulverizing mill, (Fritsch Pulverisette $2^{\oplus}$, Idar-Oberstein, Germany), which yields fractions smaller than $10 \mu \mathrm{g}$. Total carbon concentration (TCC) was obtained using a Solids TOC Analyzer (model $1020 A^{\oplus}$ ) with catalytic combustion method from $\mathrm{O} \cdot 1 \cdot$ Analytical (College Station, TX, USA) in the Soils and Fertility lab in Postgraduate College.

\section{Statistical analyses}

As classification resulted in different sample sizes, data were subjected to an unbalanced ANOVA, using the general linear model (GLM) procedure of SAS version 9.1 (SAS 2009). Differences between taxa (division, family and genus) and ecosystems were tested by one-way unbalanced ANOVAs, in which only groups with at least three samples were considered. Differences in concentration of $C$ between tree tissues were evaluated, analyzing separately the two divisions: Magnoliophyta and Pinophyta. In all analyses the carbon concentration values were transformed with the arcsine function to satisfy the assumptions of normality and homogeneity of variances. A multiple comparison between means was carried out with the post-hoc Tukey's test at $\mathrm{P}=0.05$ level.

\section{Results}

The mean $C$ concentration across species and plant parts was $44.7 \%$ (Tab. S1 in Supplementary material), varying from $44.1 \%$ to $45.8 \%$ for temperate zone species, $42.8 \%$ to $44.3 \%$ for species from tropics and subtropics and from $43.8 \%$ to $44.2 \%$ for species in arid and semiarid zones (Tab. 1). Tree species from different biomes significantly differed in $C$ concentration $(F=9.07, p=$ $0.0002)$. Species from the temperate zone had the highest C concentration (45.8\%) and those from tropical and subtropical zones the lowest (42.8\%).

Different taxa also significantly differed in $C$ concentration $(F=58.41, p<0.0001)$. The highest $C$ concentration was found for $\mathrm{Pi}$ nophyta (47.5\%), while Magnoliophyta had $3.3 \%$ less C concentration (44.2\% - Fig. 1 ). Asparagaceae and Arecaceae had the lowest $C$ concentration (43.1\%).

Carbon concentration varied between families $(F=6.72, p<0.0001)$, from $42.8 \%$ for Asparagaceae to $48.3 \%$ for Pinaceae (Tab. 2). Within family variation in C concentration was relatively low with a mean standard deviation of $1.45 \%$. Carbon concentration also differed between genera $(F=17.43, p<0.0001)$. Two main groups could be identified (Tab. 3): the first included the genus Pinus, with the highest concentration (48.96\%), while Acacia, Quercus, Bursera, Cordia, Pithecellobium and Ficus were in the second group.

Carbon concentration between plant structure differed for Pinophyta $(F=2.36$, $p=0.0128)$ and Magnoliophyta $(F=10.36$, $\mathrm{p}<0.0001$ ). For conifers, fruits, buds and bark had carbon concentrations close to $50 \%$ (Fig. 2), which were significantly higher 
than those of dead tissue of roots and branches ( $44.8 \%$ to $45.3 \%$ ). For broadleaved species, $\mathrm{C}$ concentration was higher in stem and leaves (Fig. 2).

\section{Discussion}

The common C-concentration constant used for the aerial parts of the trees is $50 \%$. This is still broadly used in large scale models of C fluxes and sinks (Becker et al. 2012, Martin et al. 2013, 2015, Gao et al. 2016). In our study, all values for $C$ concentration of 175 Mexican forest plants were below 50\% with an average value of $44.7 \%$. In agreement with other multi-species studies (Zhang et al. 2009, Martin \& Thomas 2011, Castaño-Santamaría et al. 2013), we suggest to use specific estimations for different genera and ecosystems instead of the $50 \%$ assumption. We also recommend to test the overestimation stemming from the adoption of such assumption in other ecosystems and species.

$C$ concentration was higher in temperate than in tropical tree species, which could be a result of $C$ rich volatile substances (Thomas \& Malczewski 2007, Gao et al. 2016), and lignin (Lamlom \& Savidge 2003) in species of temperate environments. In contrast, tropical trees might have less $C$ due to differences in cellulose and lignin contents (Elias \& Potvin 2003, Martin \& Thomas 2011).

C concentration was higher for Pinophyta than for Magnoliophyta, likely due to high contents of resins and other $C$ rich organic compounds in the former (Savidge 2000). Variations in C concentration between biomes were small, suggesting that $C$ concentration is relatively constant for species across environments, as already reported in other studies (Martin \& Thomas 2011, Watzlawick et al. 2014). Moreover, a large within-family variations in $C$ content was observed. This is in agreement with findings that $C$ concentration is not a strongly phylogenetically-conserved trait (Martin \& Thomas 2011). In our study the larger within-family variation was found in Pinaceae, coinciding with the findings of Yerena-Yamallel et al. (2012a). This is possibly due to differences in chemical composition of cellulose, lignin, hemicellulose, and starches (Martin et al. 2013). The high C content found in leaves compared with other tissues might be the result of higher rates of volatile compounds, as suggested by Yerena-Yamallel et al. (2012b). Other studies have also found variations of $C$ concentration between plant tissues, with higher values in leaves (Zhang et al. 2009, Durkaya et al. 2013, 2015). Because leaves differ in their longevity, their role as $C$ stocks must vary between evergreens and deciduous species (Martin \& Thomas 2011, Martin et al. 2013). The high values of C (ca. 50\%) found in bark and cones of Pinophyta in this study, could be the result of C-rich lignin and suberin in these structures (Franceschi et al. 2005).

Other studies have observed variations in

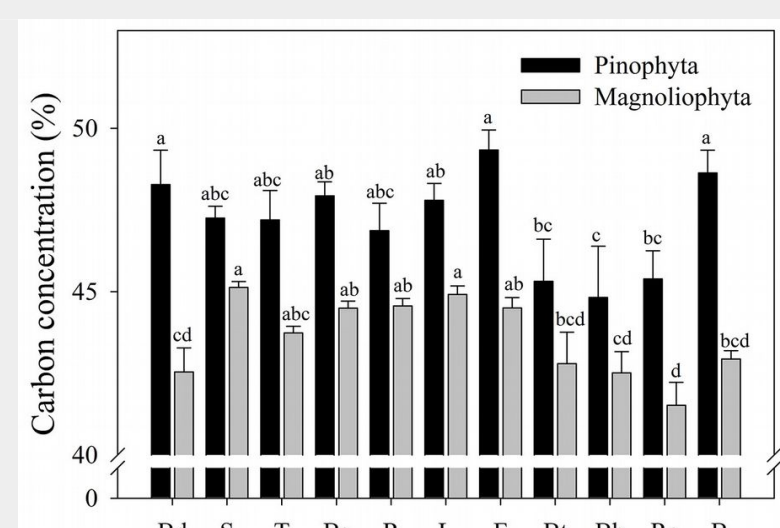

Fig. 2 - Carbon concentration for plant tissues grouped by taxonomic division. Different letters between bars of the same color indicate different means $(p<0.05)$. Leaves ( $L)$, buds (Bd), fruits $(F)$, branches $(B)$, bark from branches (Bb), twig $(<5 \mathrm{~cm}$ in diameter $\mathrm{T})$, bark from twig (Bt), stem (S), bark from stem $(\mathrm{Bs})$, roots $(\mathrm{R})$ and root cuticles $(\mathrm{Rc})$.

C concentration in dead or decaying tissue. For instance Harmon et al. (2013) found that uncertainties associated to forest $C$ inventories may be reduced using specific detritus $C$ coefficient for each taxon, instead of using the generalized $50 \%$ assumption. In dead conifer trees, as decomposition takes place, a slight increase in C concentration occurs (Cousins et al. 2015, Köster et al. 2015). Other authors argue about the relative importance of intra- vs. interspecific variation in wood $C$ for forest $C$ assessments. For instance, Martin et al. (2015) suggest that variations in C concentration between tissues of the same species are less important than variations between species for modelling $C$ dynamics in forest ecosystems. Improvement and validation of models for given ecosystems could be a viable solution, using wood density as an independent variable as suggested by some authors (Urquiza-Haas et al. 2007, Chave et al. 2014).

Reliable $\mathrm{C}$ concentration estimations are crucial for determining the role of forests in the global C cycle (Bombelli et al. 2009). The results from this study contribute to more accurate estimations of carbon concentration of plant tissues across a large number of tree species in Mexico. Even though differences between the 50\% common assumption and actual findings are small, these differences would mean gross $C$ overestimations at the scale of stands, forests or biomes (Gao et al. 2016). These could lead to $C$ content overestimations in studied Mexican forests in the order of 1.5 $\mathrm{Mg} \mathrm{ha}^{-1}$ (Yerena-Yamallel et al. 2012b) or 3.9 $M g$ ha-1 (Aguirre-Calderón \& Jiménez-Pérez 2011). Taxa-specific results contribute to a more realistic assumptions of $C$ sinks in different ecosystems (Cartus et al. 2014, Matula et al. 2015) with implications for other countries where the studied species occur and challenges the current assumption of a $50 \% \mathrm{C}$ concentration of plant tissues across forests worldwide.

\section{Conclusions}

The $C$ concentration of plant tissues for Mexican tree species differed between environments, taxa and plant tissues. Our results show that the generalized assump- tion of $50 \%$ C content is consistently slightly above real values for the species studied. This overestimation, though small in some cases, could lead to errors of $3.9 \mathrm{Mg} \mathrm{ha}^{-1}$ in some Mexican forests. To improve estimations of $C$ reserves, our values should be used for the studied genera. Given the large number of species studied, it would be important to test whether the generalized 50\% assumption does apply in other environments. It is not practical to use $C$ concentration for each plant tissue, therefore more research that models $C$ concentration indices is still necessary, especially to distinguish dead or decaying tissues. Our study contributes to a better understanding of $C$ concentration in forest ecosystems and provides a large dataset for Mexican species that can be contrasted across environments elsewhere.

\section{Acknowledgments}

Funding was provided by CONACYT (Consejo Nacional de Ciencia y Tecnología - grant CB-2013/222522). MPG, JASR carried out field and lab work; JASR, MPG, JF and EJ performed statistical analysis; MPG and EJ conceived the study and helped draft the first version manuscript. All authors wrote the manuscript. Many thanks to the landholders and foresters who allowed data collection. Direccion General de Vida Silvestre, SEMARNAT (Secretaría de Medio Ambiente y Recursos Naturales), Mexico, gave technical permit. Adrian Herrera and his staff assisted with field work. We are grateful to the anonymous reviewers for their useful comments and suggestions.

\section{References}

Aguirre-Calderón OA, Jiménez-Pérez J (2011). Evaluación del contenido de carbono en bosques del sur de Nuevo León [Carbon content evaluation in southern forests of Nuevo León]. Revista Mexicana de Ciencias Forestales 2: 7384. [in Spanish]

Avendaño D, Acosta M, Carrillo F, Etchevers J (2009). Estimación de biomasa y carbono en un bosque de Abies religiosa [Biomass and carbon estimation in an Abies religiosa woodland]. Revista Fitotecnia Mexicana 32: 233-238. [in Spanish]

Becker GS, Braun D, Gliniars R, Dalitz H (2012). 
Relations between wood variables and how they relate to tree size variables of tropical African tree species. Trees 26: 1101-1112. - doi: 10.1007/s00468-012-0687-6

Bert D, Danjon F (2006). Carbon concentration variations in the roots, stem and crown of mature Pinus pinaster (Ait.). Forest Ecology and Management 222: 279-295. - doi: 10.1016/j.for eco.2005.10.030

Bombelli A, Avitabile V, Belelli Marchesini Balzter L, Bernoux M, Hall R, Henry M, Law BE, Manlay R, Marklund LG, Shimabukuro YE (2009). Biomass - Assessment of the status of the development of the standards for the terrestrial essential climate variables. Global Terrestrial Observation System, Food and Agriculture Organization, Rome, Italy, pp. 18.

Cartus O, Kellndorfer J, Walker W, Franco C, Bishop J, Santos L, Fuentes JMM (2014). A national, detailed map of forest aboveground carbon stocks in Mexico. Remote Sensing 6: 5559-5588. - doi: 10.3390/rs6065559

Castaño-Santamaría J, Barrio-Anta M, Alvarez-Alvarez $P$ (2013). Potential above ground biomass production and total tree carbon sequestration in the major forest species in NW Spain. International Forestry Review 15: 273-289. - doi: 10.1505/146554813807700083

Cousins SJM, Battles JJ, Sanders JE, York RA (2015). Decay patterns and carbon density of standing dead trees in California mixed conifer forests. Forest Ecology and Management 353: 136-147. - doi: 10.1016/j.foreco.2015.05.030

Chave J, Réjou-Méchain $M$, Búrquez $A$, Chidumayo E, Colgan M, Delitti W, Duque A, Eid T, Fearnsid P, Goodman R, Henry M, Martínez-Yrízar A, Mugasha $W$, Muller-Landau $H$, Mencuccini $M$, Nelson B, Ngomanda A, Nogueira E, Ortiz-Malavassi E, Pélissier R, Ploton P, Ryan C, Saldarriaga J, Vieilledent $G$ (2014). Improved allometric models to estimate the aboveground biomass of tropical trees. Global Change Biology 20: 3177-3190. - doi: 10.1111/gcb.12629

Durkaya B, Durkaya A, Makineci E, Ulküdür M (2013). Estimation of above-ground biomass and sequestered carbon of Taurus Cedar ( $\mathrm{Ce}$ drus libani L.) in Antalya, Turkey. iForest 6: 278284. - doi: 10.3832/iforo899-006

Durkaya A, Durkaya B, Makineci E, Orhan I (2015). Aboveground biomass and carbon storage relationship of Turkish pines. Fresenius Environmental Bulletin 24: 3573-3583. [online] URL: http://www.researchgate.net/publication/ 288750617

Elias M, Potvin C (2003). Assessing inter- and intra-specific variation in trunk carbon concentration for 32 neotropical tree species. Canadian Journal of Forest Research 33: 1039-1045. doi: 10.1139/x03-018

Espinosa-Organista D, Ocegueda-Cruz S, AguilarZúniga C, Flores-Villela O, Llorente-Bousquets J, Vázquez-Benítez B (2008). El conocimiento biogeográfico de las especies y su regionalización natural [The biogeographical knowledgment of the species and its natural regionalization]. In: “Capital Natural de México" (Sarukhán J ed). Comisión Nacional para el Conocimiento y Uso de la Biodiversidad, DF, México, pp. 22-65. [in Spanish]

Franceschi VR, Krokene P, Christiansen E, Krekling $T$ (2005). Anatomical and chemical de- fenses of conifer bark against bark beetles and other pests. New Phytologist 167: 353-375. - doi: 10.1111/j.1469-8137.2005.01436.x

Gao B, Taylor AR, Chen HY, Wang J (2016). Variation in total and volatile carbon concentration among the major tree species of the boreal forest. Forest Ecology and Management 375: 191199. - doi: 10.1016/j.foreco.2016.05.041

González-Medrano F (2003). Las comunidades vegetales de México. Propuesta para la unificación de la clasificación y nomenclatura de la vegetación de México [The plant communities of Mexico. Proposal for the unification of the classification and nomenclature of the vegetation of Mexico]. Secretaría de Medio Ambiente y Recursos Naturales, Instituto Nacional de Ecología, DF, México, pp. 81. [in Spanish]

Harmon ME, Fasth B, Woodall CW, Sexton J (2013). Carbon concentration of standing and downed woody detritus: effects of tree taxa, decay class, position, and tissue type. Forest Ecology and Management 291: 259-267. - doi: 10.1016/j.foreco.2012.11.046

Henry M, Picard N, Manlay R, Valentini R, Bernoux $M$, Saint-André $L$ (2011). Estimating tree biomass of sub-Saharan African forests: a review of available allometric equations. Silva Fennica 45: 477-569. - doi: 10.14214/sf.38

Jiménez-Pérez J, Treviño-Garza E, Yerena-Yamallel J (2013). Concentración de carbono en especies del bosque de Pino-Encino en la Sierra Madre Oriental [Carbon concentration in species of the Pine-Oak woodland]. Revista Mexicana de Ciencias Forestales 4: 50-61. [in Spanish]

Karlik JF, Chojnacky DC (2014). Biomass and carbon data from blue oaks in a California oak savanna. Biomass and Bioenergy 62: 228-232. doi: 10.1016/j.biombioe.2013.11.018

Köster K, Metslaid M, Engelhart J, Köster E (2015). Dead wood basic density, and the concentration of carbon and nitrogen for main tree species in managed hemiboreal forests. Forest Ecology and Management 354: 35-42. doi: 10.1016/j.foreco.2015.06.039

Lamlom SH, Savidge RA (2003). A reassessment of carbon content in wood: variation within and between 41 North American species. Biomass and Bioenergy 25: 381-388. - doi: 10.1016/ Sog61-9534(03)00033-3

Martin AR, Thomas SC (2011). A reassessment of carbon content in tropical trees. PLoS ONE 6 (8): e23533. - doi: 10.1371/journal.pone.0023533 Martin AR, Thomas SC, Zhao Y (2013). Size-dependent changes in wood chemical traits: a comparison of neotropical saplings and large trees. AoB Plants 5: plt039. - doi: 10.1093/aob pla/plto39

Martin AR, Gezahegn S, Thomas SC (2015). Variation in carbon and nitrogen concentration among major woody tissue types in temperate trees. Canadian Journal of Forest Research 45: 744-757. - doi: 10.1139/cjfr-2015-0024

Matula R, Damborská L, Nečasová M, Geršl M, Srámek M (2015). Measuring biomass and carbon stock in resprouting woody plants. PLoS ONE 10 (2): e0118388. - doi: 10.1371/journal.p one. 0118388

Murray-Tortarolo $\mathrm{G}$, Friedlingstein $\mathrm{P}$, Sitch $\mathrm{S}$, Jaramillo VJ, Murguía-Flores F, Anav A, Liu Y, Arneth A, Arvanitis A, Harper A, Jain A, Kato E,
Koven C, Poulter B, Stocker BD, Wiltshire A, Zaehle S, Zeng N (2016). The carbon cycle in Mexico: past, present and future of $\mathrm{C}$ stocks and fluxes. Biogeosciences 13: 223-238. - doi: 10.5194/bg-13-223-2016

Návar J (2009). Allometric equations for tree species and carbon stock for forest of northwestern Mexico. Forest Ecology and Management 257: 427-434. - doi: 10.1016/j.foreco.2008. 09.028

Pompa-García M, Sigala-Rodríguez JA, Jurado E (2017). Some tree species of ecological importance in Mexico: a documentary review. Revista Chapingo Serie Ciencias Forestales y del Ambiente 23: 185-219. - doi: 10.5154/r.rchscfa. 2016.05.032

Rojas-García F, De Jong BH, Martínez-Zurimendí P, Paz-Pellat F (2015). Database of 478 allometric equations to estimate biomass. Annals of Forest Science 72: 835-864. - doi: 10.1007/s13 595-015-0456-y

Rzedowski J (1991). El endemismo en la flora fanerogámica mexicana: una apreciación analítica preliminar [The endemism in the Mexican phanerogamic flora: an analytical preliminar appreciation]. Acta Botanica Mexicana 15: 4764. [in Spanish] - doi: 10.21829/abm15.1991.620 Sarukhán J, Koleff P, Carabias J, Soberón J, Dirzo J, Llorente-Bousquets J, Halffter G, González R, March R, Mohar R, Anta S, De La Maza J (2009). Capital natural de México: conocimiento actual, evaluación y perspectivas de sustentabilidad [Natural capital of Mexico: actual knowledgment, evaluation and perspectives of sustentability]. Comisión Nacional para el Conocimiento y Uso de la Biodiversidad, DF, México, pp. 10o. [in Spanish]

Savidge RA (2000). Biochemistry of seasonal cambial growth and wood formation - an overview of the challenges. In: "Cell and Molecular Biology of Wood Formation. Experimental Biology Reviews" (Savidge RA, Barnett JR, Napier $\mathrm{R}$ eds). Bios Scientific Publishers Ltd, Oxford, UK, pp. 1-30.

Savidge RA (2003). Tree growth and wood quality. In: "Wood Quality and its Biological Basis" (Barnett JR, Jeronimidis G eds). CRC Press, Boca Raton, FL, USA, pp. 1-29. [online] URL: http:// www.researchgate.net/publication/311654609 Sardans J, Peñuelas J (2014). Climate and taxonomy underlie different elemental concentrations and stoichiometries of forest species: the optimum "biogeochemical niche". Plant Ecology 215: 441-455. - doi: 10.1007/s11258-014-0314-2 SAS (2009). SAS user's guide statistics. Release 9. 1. SAS Institute Inc., Cary, NC, USA, pp. 5121.

Thomas SC, Malczewski G (2007). Wood carbon content of tree species in Eastern China: Interspecific variability and the importance of the volatile fraction. Journal of Environmental Management 85: 659-662. - doi: 10.1016/j.jenvman.2006.04.022

Thomas SC, Martin AR (2012). Carbon content of tree tissues: a synthesis. Forests 3: 332-352. doi: $10.3390 /$ f3020332

Urquiza-Haas T, Dolman PM, Peres CA (2007). Regional scale variation in forest structure and biomass in the Yucatan Peninsula, Mexico: effects of forest disturbance. Forest Ecology and Management 247: 80-90. - doi: 10.1016/j.foreco. 2007.04.015 
Vieilledent G, Vaudry R, Andriamanohisoa SFD, Rakotonarivo OS, Randrianasolo $\mathrm{HZ}$, Razafindrabe $\mathrm{HN}$, Rakotoarivony $\mathrm{CB}$, Ebeling J, Rasamoelina M (2011). A universal appraoch to estimate biomass and carbon stock in tropical forests using generic allometric models. Ecological Applications 22: 572-583. - doi: 10.1890/ 11-0039.1

Watzlawick LF, Martins PJ, Rodrigues AL, Ebling A, Balbinot R, Lustosa SBC (2014). Carbon concentration in species of the araucaria forest and effect of the ecological group. Cerne 20: 613-620. - doi: 10.1590/01047760201420041492 Yeboah D, Burton AJ, Storer AJ, Opuni-Frimpong E (2014). Variation in wood density and carbon content of tropical plantation tree species from Ghana. New Forests 45: 35-52. - doi: 10.1007/s11 056-013-9390-8

Yerena-Yamallel J, Jiménez-Pérez J, Aguirre-Calderón O, Treviño-Garza E (2011). Concentración de carbono en la biomasa aérea del Matorral
Espinoso Tamaulipeco [Carbon concentration in the aereal biomass of the Tamaulipan Scrub Shrubland]. Revista Chapingo Serie Ciencias Forestales y del Ambiente 17: 283-291. [in Spanish] - doi: 10.5154/r.rchscfa.2010.02.004

Yerena-Yamallel J, Jiménez-Pérez J, Aguirre-Calderón O, Treviño-Garza E, Alanís-Rodríguez E (2012a). Concentración de carbono en el fuste de 21 especies de coníferas del noreste de México [Carbon concentration in the stem of 21 coniferous species from Northeast México]. Revista Mexicana de Ciencias Forestales 3: 4956. [in Spanish]

Yerena-Yamallel JI, Jiménez J P, Aguirre Calderón O, Treviño Garza EJ (2012b). Contenido de carbono total en los componentes de especies arbóreas y arbustivas en áreas con diferente uso, en el matorral espinoso tamaulipeco, en México [Total carbon content in the components of three and shrubby species in areas differing in use, in the Tamaulipan Scrub Shrub- land, in Mexico]. Bosque 33: 145-152. [in Spanish] - doi: 10.4067/S0717-92002012000200004 Zhang Q, Wang C, Wang X, Quan X (2009). Carbon concentration variability of 10 Chinese temperate tree species. Forest Ecology and Management 258: 722-727. - doi: 10.1016/j.foreco.20 09.05 .009

\section{Supplementary Material}

Fig. S1 - Distribution of 68 localities in Mexico from where samples were collected for $C$ concentration in 175 species.

Tab S1 - Carbon concentration to the nearest $1 \%$ for the 175 Mexican forest species studied and their tissues.

Link: Pompa-Garcia_2421@supploo1.pdf 